\title{
Solar Thermal System Evaluation in China
}

\author{
Xinyu Zhang, ${ }^{1}$ Wei Xu, ${ }^{1}$ Tao He, ${ }^{1}$ Shijun You, ${ }^{2}$ Yan Gao, ${ }^{3}$ Min Wang, ${ }^{1}$ and Bojia Li $^{1}$ \\ ${ }^{1}$ National Center for Quality Supervision and Testing of Solar Heating Systems (Beijing), China Academy of Building Research, \\ Beijing 100013, China \\ ${ }^{2}$ School of Environmental Science and Engineering, Tianjin University, Tianjin 30072, China \\ ${ }^{3}$ Beijing Key Laboratory of Green Building and Energy Efficient Technology, Beijing University of Civil Engineering and \\ Architecture, Beijing 10044, China \\ Correspondence should be addressed to Xinyu Zhang; zxyhit@163.com
}

Received 30 July 2015; Accepted 7 September 2015

Academic Editor: Xudong Zhao

Copyright (C) 2015 Xinyu Zhang et al. This is an open access article distributed under the Creative Commons Attribution License, which permits unrestricted use, distribution, and reproduction in any medium, provided the original work is properly cited.

\begin{abstract}
More than 581 solar thermal systems (STSs), 98 counties, and 47 renewable application demonstration cites in China need to be inspected by the end of 2015. In this study, the baseline for performance and economic evaluation of STSs are presented based on the site test data and related references. An index used to evaluate STSs was selected, and methods to acquire the parameters used to calculate the related index were set. The requirements for sensors for testing were specified. The evaluation method was applied to three systems and the result shows that the evaluation method is suitable for the evaluation of STSs in China.
\end{abstract}

\section{Introduction}

Buildings are responsible for most of the primary energy use in many countries and regions. In China, about $43 \%$ of primary energy is consumed in buildings [1], in the USA $41 \%$ [2], and in the EU about $40 \%$ [3]. The use of fossil energy will increase the greenhouse gas emissions and cause global climate change [4]. But, fortunately, we have abundant renewable energy. Many countries have introduced policies to encourage the application of renewable energy, especially solar energy, to reduce the consumption of primary energy [5-9]. From 2007 to 2010, in China, 581 projects, 98 counties, and 47 cities have got national financial support for the application of renewable energy in buildings. Solar thermal systems (STSs) are widely used in most of these projects, especially solar water heating systems. Solar energy can generate heat and produce power [10]. According to the statistical data from the International Energy Agency, space heating and domestic hot water consume $46 \%$ of the total energy used in residential buildings and $45 \%$ in commercial buildings [11]. The required temperature for heating and domestic hot water ranges from $30^{\circ} \mathrm{C}$ to $100^{\circ} \mathrm{C}$, and in this condition solar thermal systems have a dominant advantage for their higher energy conversion efficiency, compared with solar photovoltaic (PV) systems. Solar water heating systems (SWHS) are widely applied in many countries [12-16]. Solar heating and cooling systems are also applied in some special regions and for certain buildings [17-24].

The aim in using solar energy is to reduce the consumption of fossil energy. Can this be achieved in reality? Halawa et al. [15] compared the thermal performance evaluation of SWHS in Austria, Taiwan, and Japan and found that robust methods to assess the SWHS thermal performance in the three regions are required. This similar work is also necessary for any other regions and countries.

Many researchers have undertaken evaluations based on optimal designs and simulations. Juanicó [25] presented a new design for a roof integrated water solar collector for domestic heating and cooling in Argentina. Marcos et al. [20] designed an experimental solar energy facility to meet as much of the heating demand in a typical Spanish dwelling as possible. The system was observed to meet $65.3 \%$ of the space heating demand and $46 \%$ of the cooling demand. Hobbi and Siddiqui [26] performed an optimal design of a forced circulation solar water heating system for a residential unit in the cold Canadian climate using TRNSYS, and the fraction of solar energy for the entire system was used as the optimization parameter. Allouhi et al. [7] assessed the 
technical feasibility of a solar water heating system under Moroccan conditions using simulations. The results showed a higher solar energy fraction can be achieved in these regions when using an evacuated tube solar collector. The evaluation work by Yue and Huang [27] showed that the application of solar water heaters can cover all the energy consumption for hot water in Taiwan. Kalogirou [28, 29] analyzed the environmental benefits of domestic solar energy systems, to show that the energy spent on the manufacture and installation of a SWHS is recouped in about 1.2 years with respect to a life cycle assessment. The payback time varied from a few months to 9.5 years according to fuel costs and the particular pollutant considered with respect to the emissions produced.

Ozyogurtcu et al. [30] compared a ventilation system assisted with exhaust air heat recovery, an electric heater, and solar energy from a technoeconomic view. The results showed that the payback period of the suggested system was 5 years and 8 months. Similar work was performed by Tsoutsos et al. [31]. Al-Salaymeh et al. [32] undertook an economic investigation of an integrated boiler-solar energy saving system in Jordan. The investigation showed that using a SWHS to heat space and domestic water is cost-effective, and the payback time can be as low as 3 years under the Jordanian oil price of 2006-2008. Zhai et al. [33] proposed an energy and exergy analysis on a novel hybrid solar heating, cooling, and power generation system for a remote area in northwestern China. The case study showed that the system had a higher conversion efficiency than the conventional solar thermal power generation system alone, but the payback time was about 18 years under the conventional energy price of the year studied. Ozgener and Hepbasli $[34,35]$ performed a parametric study on the energy and exergy assessment of a solar assisted ground source heat pump system used for heating a greenhouse in Turkey, in which the peak system heat coefficient of performance (COP) was up to 2.79 on a typical hot day in Izmir, and the best exergy efficiency was $75.6 \%$.

Researchers have evaluated case studies in many countries. Michaelides and Eleftheriou [36] performed an experimental investigation on the thermal performance of a SWHS in Cyprus. The results showed that its thermal performance was relatively insensitive to solar radiation fluctuations ranging from 800 to $1000 \mathrm{~W} / \mathrm{m}^{2}$. Ayompe and Duffy [16] evaluated a solar water heating system with a heat pipe evacuated tube solar collector in Ireland based on a year of testing data from a field trial. The results showed that more attention should be paid to the heat loss from the supply pipe to improve the solar energy fraction and collector efficiency. Sekret and Turski [37] studied a solar adsorption cooling system in Poland. The real value of the cooling efficiency of the COP coefficient for the adsorption ice water generator, and real global efficiency of the adsorption system, was 0.27 and 0.23 , respectively. Ferreira Leite et al. [23] investigated a central air-conditioning system based on adsorption and solar energy in Brazil, under the mean value of the total daily solar radiation in João Pessoa. The regenerated heat supplied by solar energy was up to $75 \%$, and the COP of the adsorption chillers was found to be around 0.6. Xu et al. [38] reported on a demonstration greenhouse with a solar seasonal heat storage system in Shanghai. The interior air temperature was $15^{\circ} \mathrm{C}$ while the ambient value was $-3^{\circ} \mathrm{C}$ without any auxiliary heating equipment installed. Esen and Yuksel [39] studied applying biogas, solar, and ground source heat pump system for heating a greenhouse in Turkey and no serious defects were found in the (2009/2010) heating season, which proved the system could be used to supply the energy demand for greenhouses in the East and Southeast regions of Turkey.

It is importance to present a baseline to evaluate solar thermal system performance. Based on previous research results on STS evaluation and the STS application situation in China, the method is presented in this paper. The technical and economic aspects are considered in the method. The evaluation index and the test method for acquiring the parameters to calculate the evaluation index are also considered. The application of the method in three solar thermal systems in buildings shows that the evaluation method is suitable and can be used to evaluate the performance of a STS. The output of this research is part of the Chinese National Standard on evaluation methods for renewable energy systems applied in buildings.

\section{Scope and Evaluation Index}

2.1. Scope. The solar thermal systems referred to in this study include solar water heating, solar space heating, and solar air-conditioning systems. Thirty-seven solar thermal systems were tested by the Quality Supervision and Testing of Solar Heating Systems (Beijing) in 2009, of which 32 were solar water heating systems. Therefore, the index for evaluation is mainly based on solar water heating systems, because of their wide application in China. For solar space heating and solar air-conditioning systems, specific indices are considered. The main aim of the evaluation is to verify conformity in the system design. All of the evaluation indices should meet the design requirements. If there are no requirements during design, the evaluation index should meet related national standard requirements.

\subsection{Evaluation Index}

2.2.1. Technical Evaluation Index. The collection of solar thermal energy and ability to cope with the load should be considered during the evaluation process. Based on the test results and related references [13, 16, 17, 27, 40-42], the solar energy fraction, efficiency of the solar collecting system, and heat loss coefficient of the storage tank were selected to evaluate the thermal performance of the solar collecting system. The solar energy fraction is also related to the total energy consumption. If the solar energy fraction, efficiency of the solar collecting system, and heat loss of the storage tank are not identified during the design, the solar energy fraction should meet the requirements in Table 1, and the efficiency of the solar collecting system should meet the requirements in Table 2. The heat loss coefficient of the storage tank should be less than $30 \mathrm{~W} /\left(\mathrm{m}^{3} \cdot \mathrm{K}\right)$.

For the SWHS, the supply water temperature is taken into account and should be less than $50^{\circ} \mathrm{C}$ as required in the Chinese standard for hot water supply. For solar space heating 
TABLE 1: Requirement for the solar energy fraction in different solar energy resource regions.

\begin{tabular}{lccc}
\hline $\begin{array}{l}\text { Solar energy } \\
\text { resource } \\
\text { region }\end{array}$ & $\begin{array}{c}\text { Solar water } \\
\text { heating system }\end{array}$ & $\begin{array}{c}\text { Solar space } \\
\text { heating system }\end{array}$ & $\begin{array}{c}\text { Solar } \\
\text { air-conditioning } \\
\text { system }\end{array}$ \\
\hline Extremely rich & $f \geq 60$ & $f \geq 50$ & $f \geq 40$ \\
Abundant & $f \geq 50$ & $f \geq 40$ & $f \geq 30$ \\
Richer & $f \geq 40$ & $f \geq 30$ & $f \geq 20$ \\
Normal & $f \geq 30$ & $f \geq 20$ & $f \geq 10$ \\
\hline
\end{tabular}

Note: the solar energy resource region in Tables $1,5,6$, and 7 is divided by the annual solar hours and annual solar irradiation on the horizontals, detailed in the appendix of the Chinese national standard for solar heating system (GB 50495-2009).

TABLE 2: Requirement for the efficiency of a solar collecting system.

\begin{tabular}{lcc}
\hline $\begin{array}{l}\text { Solar water } \\
\text { heating system }\end{array}$ & $\begin{array}{c}\text { Solar space } \\
\text { heating system }\end{array}$ & $\begin{array}{c}\text { Solar } \\
\text { air-conditioning } \\
\text { system }\end{array}$ \\
\hline$\eta \geq 42$ & $\eta \geq 35$ & $\eta \geq 30$ \\
\hline
\end{tabular}

and solar air-conditioning systems, the indoor temperature is introduced. According to previous research results [17, $19,21,24,43$ ], the thermal COP is introduced to evaluate the performance of solar air-condition systems, which is the product of the efficiency of the solar collecting system and the COP of the chiller. The thermal COP indicates the ability of the solar air-conditioning system to convert solar energy to cooling capacity. To obtain a general performance of the solar air-conditioning system, the thermal COP should be given during the evaluation.

2.2.2. Economic Evaluation Index. When considering using renewable energy systems to meet the heating and cooling requirements of a building, the cost of the system is critical and can lead to an increase in the initial investment. A renewable energy system should be based on economic rationality and technical feasibility. The reasonable design of a solar thermal system should compensate the increased investment by a specific operating year during the lifetime of the system. The cost to benefit of the system is put forward. This index indicates the cost to obtain $1 \mathrm{kWh}$ energy saved during the system lifetime. It is the ratio of the increment in the system costs to the total energy saved over the whole lifetime of the system. To establish the viability of the system quickly, a simple payback period is selected. For a solar water heating system, the simple payback period should be less than 5 years, and for a solar space heating system, it should be less than 10 years. During the evaluation, the simple payback period for the solar air-conditioning system and its costbenefit should be given.

2.2.3. Environmental Evaluation Index. The aim in using renewable energy is to reduce the consumption of fossil energy. For the alternative standard, coal is selected, with which the reduction in greenhouse gas emission can be assessed. The reductions of $\mathrm{CO}_{2}, \mathrm{SO}_{2}$, and dust are the indices for environmental evaluation. These indices should be presented during the evaluation.

\section{Parameters and Requirements for the Test}

3.1. Parameters. To asses all the STSs, the efficiency of the solar collecting system, the total energy consumption, the heat gain of the collecting system, and the heat loss of the storage tank should be got. For the solar water heating system, the supply water temperature should be given to evaluate the energy quality of the system. For the solar space heating and solar air-conditioning systems, the indoor temperature should be recorded. The heating energy consumed and cooling energy supplied by the chiller only apply to the solar air-conditioning systems.

3.2. System Sampling Method. To improve the testing efficiency and reduce test cost, it is necessary to select the typical system to be evaluated.

Solar water heating systems must have the same type of solar collector, scope for solar energy collection and hot water supply, system operating mode, heat transfer media, location of the auxiliary heat source installation, and system startup mode. The difference between the gross solar collector area and storage tank must be limited to $10 \%$. Overall the system should be treated as the same type. The number of systems to be evaluated should be $2 \%$ of the same types of systems or at least one.

Solar space heating and air-conditioning systems should have the same type of solar collector, operating mode for solar energy collection, storage capacity for heating (cooling), type of chiller, and energy delivery system. The difference between the gross solar collector area, rated cooling capacity of the chiller, and heated (cooled) building area should be limited to $10 \%$ and should be treated as the same type. The number of systems evaluated should be $5 \%$ of the same type of system or at least one.

\subsection{Requirements for Meteorological Conditions}

3.3.1. System Monitoring for the Long Term. Long term monitoring of a solar water heating system should be greater than 120 successive days, the middle day of which should be the Spring or Autumn Equinox in a year.

The solar space heating system should be monitored for the whole heating season, and for the solar air-conditioning system, the monitoring time should cover the whole cooling season.

The average load during long term monitoring should be greater than $30 \%$ of the load under the design conditions.

3.3.2. Short Term Test. Short term monitoring should be over at least 4 days and performed continuously. The operating conditions should be as close to the design operating conditions as possible. The average load for a short term test should be greater than $50 \%$ of the load under the design conditions. The indoor temperature should be recorded when the building is in heat transfer equilibrium. 
TABLE 3: Accuracy and precision of instruments for temperature measurement.

\begin{tabular}{lcc}
\hline Parameter & $\begin{array}{c}\text { Instrument } \\
\text { accuracy }\end{array}$ & $\begin{array}{c}\text { Instrument } \\
\text { precision }\end{array}$ \\
\hline Temperature, ambient air & $\pm 0.5^{\circ} \mathrm{C}$ & $\pm 0.2^{\circ} \mathrm{C}$ \\
Temperature, water & $\pm 0.2^{\circ} \mathrm{C}$ & $\pm 0.1^{\circ} \mathrm{C}$ \\
\hline
\end{tabular}

The ambient temperature for the solar water heating system should be the annual average surrounding temperature $\pm 10^{\circ} \mathrm{C}$. For the solar space heating system, it should be greater than the surrounding temperature for heating load calculations and less than $12^{\circ} \mathrm{C}$. For the solar airconditioning system, it should be greater than $25^{\circ} \mathrm{C}$ and less than the dry bulb surrounding temperature for the cooling load calculations.

Results should be obtained for at least four different days with the specified solar irradiation as follows. The difference between the recorded and specified values should be $\pm 0.5 \mathrm{MJ} /\left(\mathrm{m}^{2} \cdot \mathrm{d}\right)$ :

(1) Daily solar irradiation less than $8 \mathrm{MJ} /\left(\mathrm{m}^{2} \cdot \mathrm{d}\right)$.

(2) Daily solar irradiation equal to or greater than $8 \mathrm{MJ} /\left(\mathrm{m}^{2} \cdot \mathrm{d}\right)$ and less than $12 \mathrm{MJ} /\left(\mathrm{m}^{2} \cdot \mathrm{d}\right)$.

(3) Daily solar irradiation equal to or greater than $12 \mathrm{MJ} /\left(\mathrm{m}^{2} \cdot \mathrm{d}\right)$ and less than $16 \mathrm{MJ} /\left(\mathrm{m}^{2} \cdot \mathrm{d}\right)$.

(4) Daily solar irradiation equal to or greater than $16 \mathrm{MJ} /\left(\mathrm{m}^{2} \cdot \mathrm{d}\right)$.

During the test procedure, the range for recording the solar irradiation can be adjusted based on the real situation, but an even spread is required for the solar irradiation.

3.4. Requirements for Sensors. Solar irradiation should be recorded by a pyranometer, which should meet Chinese national standard for a pyranometer (GB/T 19565).

The ambient air temperature should be measured using a shaded aspirated sampling device approximately $1 \mathrm{~m}$ above the ground, not closer than $1.5 \mathrm{~m}$ to the collector and system components and not further than $10 \mathrm{~m}$ from the system. The field-of-view of the air temperature sensor should not include chimneys, cooling towers, or hot exhaust. The sensor for measuring the water temperature should be submerged in the water. The temperate sensors and related data recorders should have a time constant of $10 \mathrm{~s}$ or less and have an accuracy and precision equal to or better than the requirements in Table 3.

The accuracy of the liquid flow rate measurement should be equal to $\pm 1.0 \%$.

Mass measurement should be accurate to $\pm 1.0 \%$.

Elapsed time measurement should be accurate to $\pm 0.2 \%$.

Analog and digital recorders used should have an accuracy equal to or better than $\pm 0.5 \%$ of the full scale reading and have a time constant of 1 second or less. Digital techniques and electronic integrators used should have accuracy equal to or better than $1.0 \%$ of the measured value. The input impedance of recorders should be greater than 1000 times the impedance of the sensors or $10 \mathrm{M} \Omega$, whichever is the higher.
In no case should the smallest scale division of the instrument or instrument exceed twice the specified precision.

Length measurement should be made with an accuracy of $\pm 1.0 \%$.

The accuracy for the heat meter should be class 2 according to the Chinese construction industry standard for heat meters (CJ128).

\section{Method to Determine the Parameters}

4.1. Efficiency of Solar Collecting System. For the short term test, the daily test starts at $8 \mathrm{am}$, and when the accumulated solar irradiation meets the requirement of the specified value, the circulation is stopped. The efficiency of solar collecting system can be expressed by

$$
\eta=\frac{Q_{j}}{A H}
$$

where $\eta$ is the efficiency of the solar collecting system, $A$ the solar collector's area in $\mathrm{m}^{2}, H$ the solar irradiation on the aperture area of the solar collector in $\mathrm{MJ} / \mathrm{m}^{2}$, and $Q_{j}$ the useful energy gained in units of MJ, which can be expressed by

$$
Q_{j}=\sum_{i=1}^{n} m_{j i} \rho_{w} c_{p w}\left(t_{d j i}-t_{b j i}\right) \Delta T_{j i} \times 10^{-6},
$$

where $m_{j i}$ is the average flow rate of solar collecting system in $\mathrm{m}^{3} / \mathrm{s}, c_{p w}$ is the constant specific heat of the heat transfer media in $\mathrm{J} / \mathrm{kg} .{ }^{\circ} \mathrm{C}, \rho_{w}$ is the density of the heat transfer media in $\mathrm{kg} / \mathrm{m}^{3}, t_{d j i}$ is the inlet temperature of the solar collecting in the efficiency of the solar collecting system in ${ }^{\circ} \mathrm{C}, t_{b j i}$ is the outlet temperature of the solar collecting in the efficiency of the solar collecting system in ${ }^{\circ} \mathrm{C}, \Delta T_{j i}$ is the recorded time interval in seconds and $\Delta T_{j i}$ should be less than $600 \mathrm{~s}$, and $n$ is the total number of recorded data. The useful energy gained can be acquired by testing the flow rate, the inlet and outlet temperature of the solar collecting system or by using a heat meter.

4.2. Total Energy Consumption. For short term monitoring, the duration for total energy consumption ranges between 8:00 and 8:00 the next morning.

The total energy consumption can be acquired using the flow rate and two temperatures or using a heat meter. It can be expressed as

$$
Q_{z}=\sum_{i=1}^{n} m_{z i} \rho_{w} c_{p w}\left(t_{d z i}-t_{b z i}\right) \Delta T_{z i} \times 10^{-6},
$$

where $Q_{z}$ is the total energy consumption in units of $M J$, $m_{z i}$ the average flow rate of the system in $\mathrm{m}^{3} / \mathrm{s}, t_{d z i}$ the hot water temperature supplied by the solar water heating system or the supply water temperature for the solar space heating system or the return water temperature for the solar aircondition system supply water temperature in ${ }^{\circ} \mathrm{C}, t_{b z i}$ the cold water temperature for the solar water heating system or 
the return water temperature for the solar space heating system or the supply water temperature for the solar airconditioning system in ${ }^{\circ} \mathrm{C}$, and $\Delta T_{z i}$ the recording time interval in seconds which should be less than $600 \mathrm{~s}$.

During the test for total energy consumption, the hot water supplied by the solar water heating system, and the indoor temperatures for the solar heating and solar airconditioning systems, should be recorded at the same time each day. The hot water temperature and indoor temperature should be the arithmetic average of the recorded data.

\subsection{Heating Energy Consumed and Cooling Energy Supplied} by the Chiller. For short term monitoring, the duration for the heating energy consumed and cooling energy supplied by the chiller ranges between 8:00 and 8:00 the next morning, and before recording the test data, the chiller should operate stably for an hour.

The heating energy consumed and cooling energy supplied by the chiller can be acquired from the flow rate and the two temperatures or using the heat meter. The heating energy consumed by the chiller can be expressed by

$$
q_{r}=\frac{\sum_{i=1}^{n} m_{r i} \rho_{w} c_{p w}\left(t_{d r i}-t_{b r i}\right) \Delta T_{r i} \times 10^{-3}}{\Delta T},
$$

where $q_{r}$ is the heating energy consumed by the chiller in units of $\mathrm{kW}, m_{r i}$ the average flow rate system in $\mathrm{m}^{3} / \mathrm{s}, t_{d r i}$ the supply water temperature to the chiller in ${ }^{\circ} \mathrm{C}, t_{b r i}$ the return water temperature from the chiller in ${ }^{\circ} \mathrm{C}, \Delta T_{r i}$ the recording time interval in seconds, which should be less than $600 \mathrm{~s}$, and $\Delta T_{t}$ the total recording time in seconds.

The cooling energy supplied by the chiller should be

$$
q_{l}=\frac{\sum_{i=1}^{n} m_{l i} \rho_{w} c_{p w}\left(t_{d l i}-t_{b l i}\right) \Delta T_{l i} \times 10^{-3}}{\Delta T_{t}},
$$

where $q_{l}$ is the cooling energy supplied by the chiller in units of $\mathrm{kW}, m_{l i}$ the average flow rate system in $\mathrm{m}^{3} / \mathrm{s}, t_{d l i}$ the return water temperature to the chiller in ${ }^{\circ} \mathrm{C}, t_{b l i}$ the supply water temperature from the chiller in ${ }^{\circ} \mathrm{C}$, and $\Delta T_{l i}$ the recording time interval in seconds which should be less than $600 \mathrm{~s}$.

4.4. Heat Loss Coefficient of Storage Tank. The test for the heat loss coefficient of the storage tank lasts from 20:00 to 6:00 the next morning. During the test, no cold water should enter the tank and no hot water should leave the tank. The start temperature for the test should be higher than $50^{\circ} \mathrm{C}$, and the temperature difference between the temperature in the tank and surrounding air temperature should be greater than $20 \mathrm{~K}$.

The heat loss coefficient of the storage tank can be expressed as

$$
U_{\mathrm{SL}}=\frac{\rho_{w} c_{p w} \ln \left[\left(t_{i}-t_{\mathrm{as}(\mathrm{av})}\right) /\left(t_{f}-t_{\mathrm{as}(\mathrm{av})}\right)\right]}{\Delta \tau},
$$

where $U_{\mathrm{SL}}$ is the heat loss coefficient of the storage tank in $\mathrm{W} /\left(\mathrm{m}^{3} \cdot \mathrm{K}\right), \Delta \tau$ the duration of the heat loss test in seconds, $t_{i}$ the initial temperature in the tank at the beginning of the test in ${ }^{\circ} \mathrm{C}, t_{f}$ the final temperature in the tank after the heal loss test in ${ }^{\circ} \mathrm{C}$, and $t_{\text {as(av) }}$ the average surrounding air temperature during the heat loss test in ${ }^{\circ} \mathrm{C}$.

\section{Evaluation}

5.1. Technical Evaluation. Initially, the hot water temperature and the indoor temperature should meet the related standard requirements, and then the evaluation can proceed. The heat loss coefficient of the storage tank should be less than $30 \mathrm{~W} /\left(\mathrm{m}^{3} \cdot \mathrm{K}\right)$.

5.1.1. Solar Energy Fraction. The solar energy fraction is expressed as

$$
f=\frac{Q_{j}}{Q_{z}} .
$$

For long duration system monitoring, the solar energy fraction should be the average value. For the short term test, expressed as

$$
f=\frac{\left(x_{1} f_{1}+x_{2} f_{2}+x_{3} f_{3}+x_{4} f_{4}\right)}{\left(x_{1}+x_{2}+x_{3}+x_{4}\right)},
$$

where $f_{1}, f_{2}, f_{3}$, and $f_{4}$ are the solar energy fractions for the four tested solar irradiations and $x_{1}, x_{2}, x_{3}$, and $x_{4}$ the numbers of days that have one of the four specified solar irradiations in a year.

5.1.2. Efficiency of Solar Collecting System. For long duration system monitoring, the efficiency of the solar collecting system should be the average value. For the short term test, expressed as

$$
\eta=\frac{\left(x_{1} \eta_{1}+x_{2} \eta_{2}+x_{3} \eta_{3}+x_{4} \eta_{4}\right)}{\left(x_{1}+x_{2}+x_{3}+x_{4}\right)},
$$

where $\eta_{1}, \eta_{2}, \eta_{3}$, and $\eta_{4}$ are the efficiency of the solar collecting system for the four tested solar irradiations determined by (1).

5.1.3. Thermal COP for Solar Air-Conditioning System. Thermal COP for the solar air-conditioning system is expressed by

$$
\mathrm{COP}_{r}=\eta\left(\frac{q_{l}}{q_{r}}\right),
$$

where $\mathrm{COP}_{r}$ is the thermal COP for the solar air-conditioning system.

\subsection{Economic Evaluation}

5.2.1. Cost-Benefit for the System. The cost-benefit for the system is related to the amount of energy saved in the lifetime of the system and the investment, expressed as

$$
\mathrm{CBR}_{r}=3.6 \times \frac{C_{z r}}{\left(Q_{t r} q N\right)},
$$


TABLE 4: Operating efficiency of a heating resource using conventional energy.

\begin{tabular}{lccc}
\hline $\begin{array}{l}\text { Conventional } \\
\text { energy }\end{array}$ & $\begin{array}{c}\text { Domestic } \\
\text { water }\end{array}$ & $\begin{array}{c}\text { Space } \\
\text { heating }\end{array}$ & $\begin{array}{c}\text { Thermal } \\
\text { driven } \\
\text { cooling }\end{array}$ \\
\hline Electricity & 0.31 & $/$ & $/$ \\
Coal & $/$ & 0.70 & 0.70 \\
Natural gas & 0.84 & 0.80 & 0.80 \\
\hline
\end{tabular}

where $\mathrm{CBR}_{r}$ is the cost-benefit for the system in $¥ \mathrm{RMB} / \mathrm{kWh}$, $C_{z r}$ the added investment for the use of STS in $¥ \mathrm{RMB}$, $q$ the heat value of standard coal (in China this value is 29.307 MJ/(kgce)), $N$ the lifetime of the system (normally it should be 15 years), and $Q_{t r}$ the amount of alternative energy in kgce, expressed as

$$
Q_{t r}=\frac{Q_{n j}}{q \eta_{t}},
$$

where $\eta_{t}$ is the operating efficiency of the heat resource with conventional energy (if not given in related files, it can be decided in Table 4) and $Q_{n j}$ the useful heat gain yearly in MJ. For the long term monitoring, it should be the accumulated value during the monitoring, and for the short test, it is expressed as

$$
Q_{n j}=x_{1} Q_{j 1}+x_{2} Q_{j 2}+x_{3} Q_{j 3}+x_{4} Q_{j 4} \text {, }
$$

where $Q_{j 1}, Q_{j 2}, Q_{j 3}$, and $Q_{j 4}$ are the useful energy gained from the four tested solar irradiations determined by (2) in MJ.

5.2.2. Simple Payback Year. The simple payback period can be expressed as

$$
N_{h}=\frac{C_{z r}}{C_{s r}}
$$

where $C_{s r}$ is saved cost in $¥ \mathrm{RMB}$ and can be expressed by

$$
C_{s r}=P Q_{t r} \frac{q}{3.6}-M_{r}
$$

where $P$ is the price of conventional energy in $¥ \mathrm{RMB} / \mathrm{kWh}$ and $M_{r}$ is the cost for system maintenance in $¥ \mathrm{RMB}$.

\subsection{Environmental Evaluation}

5.3.1. Reduction Emission of $\mathrm{CO}_{2}$. The reduction emission of $\mathrm{CO}_{2}$ can be expressed by

$$
E_{\mathrm{rCO}_{2}}=Q_{t r} V_{\mathrm{CO}_{2}},
$$

where $E_{\mathrm{rCO}_{2}}$ is the reduction emission of $\mathrm{CO}_{2}$ in $\mathrm{kg}$ and $V_{\mathrm{CO}_{2}}$ the emission factor of $\mathrm{CO}_{2}$ in $\mathrm{kg} / \mathrm{kgce}$ (it is $2.47 \mathrm{~kg} / \mathrm{kgce}$ ).

5.3.2. Reduction Emission of $\mathrm{SO}_{2}$. The reduction emission of $\mathrm{SO}_{2}$ is expressed by

$$
E_{r \mathrm{SO}_{2}}=\mathrm{Q}_{t r} V_{\mathrm{so}_{2}},
$$

where $E_{\mathrm{rsO}_{2}}$ is the reduction emission of $\mathrm{SO}_{2}$ in $\mathrm{kg}$ and $V_{\mathrm{SO}_{2}}$ the emission factor of $\mathrm{SO}_{2}$ in $\mathrm{kg} / \mathrm{kgce}$ (it is $0.02 \mathrm{~kg} / \mathrm{kgce}$ ).
TABLE 5: Rank of the solar energy fraction for a solar water heating system in different solar energy resource regions.

\begin{tabular}{lccc}
\hline $\begin{array}{l}\text { Solar energy } \\
\text { resource } \\
\text { region }\end{array}$ & Rank 1 & Rank 2 & Rank 3 \\
\hline $\begin{array}{l}\text { Extremely } \\
\text { rich }\end{array}$ & $f \geq 80$ & $80>f \geq 70$ & $70>f \geq 60$ \\
Abundant & $f \geq 70$ & $70>f \geq 60$ & $60>f \geq 50$ \\
Richer & $f \geq 60$ & $60>f \geq 50$ & $50>f \geq 40$ \\
Normal & $f \geq 50$ & $50>f \geq 40$ & $40>f \geq 30$ \\
\hline
\end{tabular}

TABLE 6: Rank of the solar energy fraction for a solar space heating system in different solar energy resource regions.

\begin{tabular}{llcc}
\hline $\begin{array}{l}\text { Solar energy } \\
\text { resource } \\
\text { region }\end{array}$ & Rank 1 & Rank 2 & Rank 3 \\
\hline Extremely rich & $f \geq 70$ & $70>f \geq 60$ & $60>f \geq 50$ \\
Abundant & $f \geq 60$ & $60>f \geq 50$ & $50>f \geq 40$ \\
Richer & $f \geq 50$ & $50>f \geq 40$ & $40>f \geq 30$ \\
Normal & $f \geq 40$ & $40>f \geq 30$ & $30>f \geq 20$ \\
\hline
\end{tabular}

TABLE 7: Rank of the solar energy fraction for a solar airconditioning system in different solar energy resource regions.

\begin{tabular}{llcc}
\hline $\begin{array}{l}\text { Solar energy } \\
\text { resource } \\
\text { region }\end{array}$ & Rank 1 & Rank 2 & Rank 3 \\
\hline Extremely rich & $f \geq 60$ & $60>f \geq 50$ & $50>f \geq 40$ \\
Abundant & $f \geq 50$ & $50>f \geq 40$ & $40>f \geq 30$ \\
Richer & $f \geq 40$ & $40>f \geq 30$ & $30>f \geq 20$ \\
Normal & $f \geq 30$ & $30>f \geq 20$ & $20>f \geq 10$ \\
\hline
\end{tabular}

5.3.3. Reduction Emission of Dust. The reduction emission of dust can be expressed by

$$
E_{r f c}=Q_{t r} V_{f c}
$$

where $E_{r f c}$ is the reduction emission of dust in $\mathrm{kg}$ and $V_{f c}$ is the emission factor of dust in $\mathrm{kg} / \mathrm{kgce}$ (it is $0.01 \mathrm{~kg} / \mathrm{kgce}$ ).

\section{Assessment and Rank for STS}

Each index should meet the requirements in Section 2.2, at which point the assessment result is passed. If one index performs poorly, the assessment cannot be passed. If the solar energy fraction and efficiency of the solar collecting system are equal to or greater than the values in Tables 1 and 2, the performance of the STS can be ranked. There are 3 levels of rank for the solar energy fraction, with rank 1 being the highest. The type of STS and solar energy resource considered during the ranking are detailed in Tables 5-7. There are also 3 levels of rank for the efficiency of the solar collecting system, with rank 1 being the highest. The type of STS considered during the ranking is detailed in Table 8 . The rank for solar energy fraction and the efficiency of the solar collecting system are the same, as is the final rank for STS. If 
TABLE 8: Rank of the efficiency for a solar collecting system.

\begin{tabular}{lccc}
\hline Rank & $\begin{array}{c}\text { Solar water } \\
\text { heating system }\end{array}$ & $\begin{array}{c}\text { Solar space } \\
\text { heating system }\end{array}$ & $\begin{array}{c}\text { Solar } \\
\text { air-conditioning } \\
\text { system }\end{array}$ \\
\hline Rank 1 & $\eta \geq 65$ & $\eta \geq 60$ & $\eta \geq 55$ \\
Rank 2 & $65>\eta \geq 50$ & $60>\eta \geq 45$ & $55>\eta \geq 40$ \\
Rank 3 & $50>\eta \geq 42$ & $45>\eta \geq 35$ & $40>\eta \geq 30$ \\
\hline
\end{tabular}

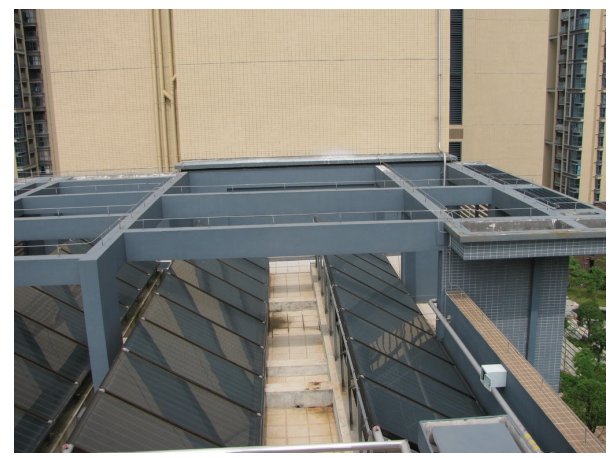

FIGURE 1: Flat plate solar collectors for solar water heating system in Shenzhen.

the ranks for the solar energy fraction and the efficiency of the solar collecting system are different, the rank for the STS is the lower. For instance, if the rank for the solar energy fraction is rank 1 , the rank for the efficiency of the solar collecting system is rank 3 , and the final rank for STS will be 3 .

\section{Application of the Evaluation System with Short Term Test Data}

\subsection{Solar Water Heating System for an Apartment in Shenzhen}

7.1.1. Description of Solar Water Heating Systems. For the systems located in Baoan, Shenzhen city, the design requirement is that the system can supply each resident $60 \mathrm{~L}$ hot water with the temperature of $55^{\circ} \mathrm{C}$. A $490 \mathrm{~m}^{2}$ flat plate solar collector was used and installed on the roof (Figure 1), and an electricity heater was used as a backup heat resource.

7.1.2. Test Results. Detailed test results are given in Table 9. Based on (8), the yearly solar energy fraction was $73 \%$. The solar collecting system was $44 \%$ efficient.

The test result for the heat loss coefficient of the storage tank was $14 \mathrm{~W} /\left(\mathrm{m}^{3} \cdot{ }^{\circ} \mathrm{C}\right)$. The average temperature of the supplied hot water was $55.6^{\circ} \mathrm{C}$ during the test.

The cost-benefit of the system was $0.15 ¥ \mathrm{RMB} / \mathrm{kWh}$, less than the electricity price in Shenzhen, which was $0.70 ¥ \mathrm{RMB} / \mathrm{kWh}$, implying the solar water heating system can save electricity in domestic water heating.

The simple payback period was 2.8 years. The yearly reductions in emission of $\mathrm{CO}_{2}, \mathrm{SO}_{2}$, and dust were $63138 \mathrm{~kg}$, $511 \mathrm{~kg}$, and $256 \mathrm{~kg}$, respectively.

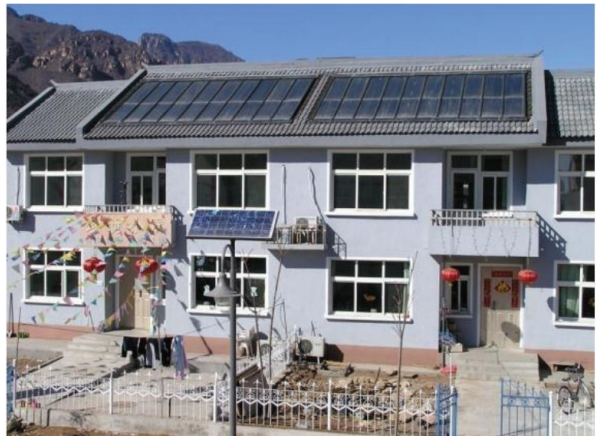

FIGURE 2: Flat plate solar collectors integrated with slope roof for solar space heating system in Beijing.

7.1.3. Evaluation and Rank. Shenzhen is located in a richer solar energy resource region. Comparing the test results with the data in Tables 1 and 2, the solar energy fraction and efficiency of the solar collecting system were greater than requirements. Therefore, the system passed the final evaluation. According to Table 5, the rank for the system should be rank 1 . According to Table 8 , the rank for the system should be rank 3 , so the final rank for the system was rank 3 .

During the ranking procedure, it was found that the solar energy fraction for the system was greater than the requirement, but the efficiency of the solar collecting system was relatively lower compared with other systems. This led to an increase in initial investment and the operating temperature of the solar collecting system was at a higher level. It is possible that the solar water heating system can perform better and at a lower cost in the present situation.

\subsection{Solar Space Heating System for a Rural Residential Building in Beijing}

7.2.1. Description of the Solar Water Heating Systems. The systems are located in Pinggu, Beijing, and were part of a demonstration project for a rural area in Beijing to save energy and improve indoor air quality. The building was a typical rural house in the south of China with a floor area of $160 \mathrm{~m}^{2}$. A flat plate solar collector was used and integrated with the slope of the roof (Figure 2). The aperture area was $24.21 \mathrm{~m}^{2}$. The system supplied energy for space heating and domestic water. Two tanks were used in the system, one tank of $1500 \mathrm{~L}$ to store heat and another of $100 \mathrm{~L}$ for hot water. The small scale boiler with higher efficiency was used as backup energy. The fuel for the boiler was coal.

7.2.2. Test Results. The test was performed during the hot season. Detailed test results are given in Table 10.

Based on (8), the solar energy fraction for heating was $41 \%$, and the average indoor temperature during the test was $16.9^{\circ} \mathrm{C}$, as detailed in Table 11 . The test result for the solar energy fraction during the season without a heating requirement was $91 \%$.

For the efficiency of the solar collecting system during heating, the test result was $51 \%$. The solar collecting system 
TABLE 9: Test results for a solar water heating system.

\begin{tabular}{cccccccc}
\hline Number & $\begin{array}{c}\text { Ambient } \\
\text { temperature }\end{array}$ & $\begin{array}{c}\text { Solar irradiation } \\
\mathrm{MJ} / \mathrm{m}^{2}\end{array}$ & $\begin{array}{c}\text { Useful heat } \\
\text { gain } \\
\text { MJ }\end{array}$ & $\begin{array}{c}\text { Total energy } \\
\text { consumption } \\
\text { MJ }\end{array}$ & $\begin{array}{c}\text { Efficiency of } \\
\text { solar collecting } \\
\text { system }\end{array}$ & $\begin{array}{c}\text { Solar energy } \\
\text { fraction }\end{array}$ & $\begin{array}{c}\text { Consumed hot } \\
\text { water } \\
\mathrm{m}^{3}\end{array}$ \\
\hline 1 & 25.9 & 7.82 & 239.4 & 697.2 & 0.33 & 0.34 & 7.81 \\
2 & 27.3 & 12.74 & 474.1 & 977.3 & 0.40 & 0.49 & 7.54 \\
3 & 28.4 & 20.48 & 942.3 & 941.6 & 0.50 & 1.00 & 7.93 \\
4 & 30.2 & 17.96 & 839.4 & 838.6 & 0.51 & 1.00 & 8.05 \\
\hline
\end{tabular}

TABLE 10: Test results for a solar space heating system during heating conditions.

\begin{tabular}{|c|c|c|c|c|c|c|c|}
\hline Number & $\begin{array}{c}\text { Solar } \\
\text { irradiation }\end{array}$ & $\begin{array}{l}\text { Useful heat } \\
\text { gain }\end{array}$ & $\begin{array}{c}\text { Energy } \\
\text { consumed for } \\
\text { space heating }\end{array}$ & $\begin{array}{c}\text { Energy } \\
\text { consumption } \\
\text { for domestic } \\
\text { water }\end{array}$ & $\begin{array}{l}\text { Energy consumed of } \\
\text { conventional energy }\end{array}$ & $\begin{array}{l}\text { Efficiency of solar } \\
\text { collecting system }\end{array}$ & $\begin{array}{c}\text { Solar energy } \\
\text { fraction }\end{array}$ \\
\hline & $\mathrm{MJ} / \mathrm{m}^{2}$ & MJ & $\mathrm{MJ}$ & MJ & $\mathrm{MJ}$ & & \\
\hline 1 & 17.0 & 233.7 & 379.7 & 20.6 & 216.9 & 0.57 & 0.52 \\
\hline 2 & 12.6 & 173.9 & 361.1 & 15.9 & 247.3 & 0.57 & 0.41 \\
\hline 3 & 7.0 & 38.16 & 180.4 & 0.7 & 184.3 & 0.23 & 0.17 \\
\hline 4 & 22.1 & 288.3 & 360.0 & 5.8 & 157.7 & 0.54 & 0.65 \\
\hline
\end{tabular}

TABLE 11: Indoor air temperature test results during heating conditions.

\begin{tabular}{lcccc}
\hline Number & $\begin{array}{c}\text { 2nd living } \\
\text { room } \\
{ }^{\circ} \mathrm{C}\end{array}$ & $\begin{array}{c}\text { 1st living } \\
\text { room } \\
{ }^{\circ} \mathrm{C}\end{array}$ & $\begin{array}{c}\text { 2nd bed room } \\
\text { with south } \\
\text { window } \\
{ }^{\circ} \mathrm{C}\end{array}$ & $\begin{array}{c}\text { Outside } \\
\text { airspeed } \\
\mathrm{M} \cdot \mathrm{s}^{-1}\end{array}$ \\
\hline 1 & 16.5 & 17.8 & 16.3 & 1.11 \\
2 & 15.9 & 18.0 & 14.6 & 0.85 \\
3 & 14.7 & 18.2 & 14.1 & 0.65 \\
4 & 19.3 & 19.8 & 17.7 & 0.72 \\
\hline
\end{tabular}

was often overheating which was an abnormal condition during the season without any heating requirements.

The test result for the heat loss coefficient of both tanks was $15 \mathrm{~W} /\left(\mathrm{m}^{3} \cdot{ }^{\circ} \mathrm{C}\right)$.

The cost-benefit of the system was $0.66 ¥ \mathrm{RMB} / \mathrm{kWh}$, which was higher than the electricity price in Beijing, at $0.52 ¥ \mathrm{RMB} / \mathrm{kWh}$. This implied the cost of a solar space heating system for water heating was too high, so the simple payback period was up to 13.5 years, if one considered the interest on money and investment requirement that the cost should be paid back during the lifetime of the system.

The yearly reductions in the emission of $\mathrm{CO}_{2}, \mathrm{SO}_{2}$, and dust were $3058 \mathrm{~kg}, 25 \mathrm{~kg}$, and $13 \mathrm{~kg}$, respectively.

7.2.3. Evaluation and Rank. Beijing is located in a richer solar energy resource region, and comparing the test results with the data in Tables 1 and 2, the solar energy fraction and efficiency of the solar collecting system were greater than the requirements. Therefore the system passed its final evaluation. According to Tables 6 and 8, the system should be at rank 2 , so the final rank for the system was rank 2 .

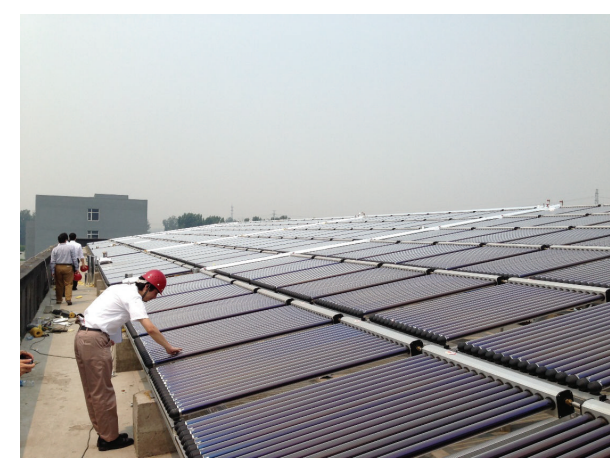

FIgURE 3: Evacuated tube solar collector for solar air-conditioning system in Beijing.

The rank of the solar space heating system in this project seemed good, but from an economic view, the result is not acceptable. The test was performed during the first year. As time passes, the performance of a solar collector can deteriorate, which was proved by Zhang et al. [44]. This problem should be considered in further applications of solar heating systems.

\subsection{Solar Air-Conditioning System for an Office in Beijing}

7.3.1. Description of Solar Air-Conditioning Systems. This system was located in Beijing and supplied cooling energy in summer and heat in winter. The floor area for this office was $1850 \mathrm{~m}^{2}$ over two floors. The $\mathrm{U}$ type evacuated tube solar collector was used with an aperture area of $457 \mathrm{~m}^{2}$ and installed on the flat roof of the building (Figure 3). To make full use of the solar energy in summer, the slope of the solar collector frame was $25^{\circ}$. The total investment in the heating and air-conditioning system was $1.39 \mathrm{M} ¥ \mathrm{RMB}$, 
TABLE 12: Equipment for a solar air-conditioning system.

\begin{tabular}{|c|c|c|}
\hline \multirow{6}{*}{$\begin{array}{l}\text { Solar } \\
\text { collecting } \\
\text { system }\end{array}$} & Type & $\begin{array}{l}\text { Indirect, forced } \\
\text { circulation }\end{array}$ \\
\hline & Solar collector & $\begin{array}{l}\text { U type evacuated tube } \\
\text { solar collector }\end{array}$ \\
\hline & Heat transfer media & Water \\
\hline & Number of storage tanks & 1 \\
\hline & Tank volume & $15 \mathrm{~m}^{3}$ \\
\hline & $\begin{array}{l}\text { Insulation material and } \\
\text { thickness }\end{array}$ & $50 \mathrm{~mm}$ polyurethane \\
\hline \multirow{5}{*}{$\begin{array}{l}\text { Refrigeration } \\
\text { system }\end{array}$} & Type of refrigerator & WFC-SC50 \\
\hline & $\begin{array}{l}\text { Cooling capacity of } \\
\text { refrigerator }\end{array}$ & Cooling capacity $176 \mathrm{~kW}$ \\
\hline & Manufacture & Yazaki \\
\hline & Number of storage tanks & 1 \\
\hline & Tank volume & $8 \mathrm{~m}^{3}$ \\
\hline Backup & Type & Biomass boiler \\
\hline
\end{tabular}

and the investment in the solar air-conditioning system was $0.45 \mathrm{M}$ ₹MB. The details of the equipment in the system are given in Table 11.

7.3.2. Test Results. The tests were performed in both hot and cold seasons. Details of the test results for the cold season are in Table 12.

The test result for the solar energy fraction for cooling was $83 \%$, the efficiency of the solar collecting system $50 \%$, the thermal COP 0.41, and the average indoor temperature $25.6^{\circ} \mathrm{C}$. The test result for the heat loss coefficient of the heat storage tank is $3 \mathrm{~W} /\left(\mathrm{m}^{3} \cdot{ }^{\circ} \mathrm{C}\right)$.

The cost saved during the cooling season was $42 \mathrm{k} ¥ \mathrm{RMB}$, the cost-benefit of the system during cooling season was $0.15 ¥ \mathrm{RMB} / \mathrm{kWh}$, and the simple payback period was 10.7 years. The reductions in emissions of $\mathrm{CO}_{2}, \mathrm{SO}_{2}$, and dust during the cooling season were $593,000 \mathrm{~kg}, 480 \mathrm{~kg}$, and $240 \mathrm{~kg}$, respectively.

Details for the test results for the cold season are given in Table 13.

The test result for the solar energy fraction for heating was $72 \%$, the efficiency of the solar collecting system was $43 \%$, and the average indoor temperature was $22.0^{\circ} \mathrm{C}$. The cost saved during the hot season was $15 \mathrm{k} ¥ \mathrm{RMB}$. Details for the test results for heat season are given in Table 14.

Considering all the results of the cold and hot seasons, the cost-benefit for the system was $0.09 ¥ \mathrm{RMB} / \mathrm{kWh}$, and the simple payback period was 7.9 years. The reductions in emissions of $\mathrm{CO}_{2}, \mathrm{SO}_{2}$, and dust were $960,000 \mathrm{~kg}, 779 \mathrm{~kg}$, and $389 \mathrm{~kg}$, respectively.

7.3.3. Evaluation and Rank. Beijing is located in a richer solar energy resource region, and comparing the test results with the data in Tables 1 and 2, the solar energy fraction and efficiency of the solar collecting system were greater than the requirements. Therefore the system passed its final evaluation. Based on the test results for the cooling season, according to Table 7, the rank for the solar air-conditioning system should be rank 1 . According to Table 8 , the rank for the solar air-conditioning system should be rank 2 , so the final rank for the solar air-conditioning system was rank 2 .

From the evaluation, the solar air-conditioning system was able to match the load requirements for different seasons.

\section{Conclusions}

Through the research, an evaluation method for solar thermal systems was presented. It has provided a baseline for the evaluation of many systems in China. The output of the research is part of Chinese national standard (GB/T 50801). The evaluation method was applied to three systems and the result showed that the evaluation method was suitable for the acceptance inspection of STSs.

During the application of the standard, some improvements were found. More index should be added for comprehensive evaluations of systems. The solar energy fraction can be changed to be expressed with different parameters that can be closer to the real situation. The payback period should be considered with more factors, and saving energy not taken into account, depending on the type of backup energy used.

\section{Nomenclature}

A: $\quad$ Aperture area of solar collector, $\mathrm{m}^{2}$

$c_{p w}: \quad$ Constant specific heat, $\mathrm{kJ} /\left(\mathrm{kg} \cdot{ }^{\circ} \mathrm{C}\right)$

$\mathrm{CBR}_{r}$ : Cost-benefit for system, RMB¥/kWh

$C_{z r}: \quad$ Added investment for the use of STS, RMB¥

$C_{s r}: \quad$ Saved cost, RMB¥

$E_{\mathrm{rCO}_{2}}$ : Reduction emission of $\mathrm{CO}_{2}, \mathrm{~kg} / \mathrm{kgce}$

$E_{r f c}:$ Reduction emission of dust, $\mathrm{kg} / \mathrm{kgce}$

$E_{\mathrm{rSO}_{2}}$ : Reduction emission of $\mathrm{SO}_{2}, \mathrm{~kg} / \mathrm{kgce}$

$H$ : Solar irradiation on the aperture of solar collector, $\mathrm{MJ} / \mathrm{m}^{2}$

$m_{j i}$ : Average flow rate of solar collecting system, $\mathrm{m}^{3} / \mathrm{s}$

$m_{l i}: \quad$ Average flow rate of cooling water from the chiller, $\mathrm{m}^{3} / \mathrm{s}$

$m_{r i}$ : Average flow rate of heating water to the chiller, $\mathrm{m}^{3} / \mathrm{s}$

$m_{z i}$ : Average flow rate of the system, $\mathrm{m}^{3} / \mathrm{s}$

$n: \quad$ Total numbers of recorded data

$N$ : $\quad$ Lifetime of the system

$N_{h}$ : Simple payback year

$q$ : $\quad$ Heat value of standard coal, MJ/(kgce)

$q_{l}$ : Cooling energy supplied by the chiller, $\mathrm{kW}$

$q_{r}$ : Heating energy consumed by the chiller, $\mathrm{kW}$

$Q_{n j}: \quad$ Useful heat gain yearly, MJ

$Q_{j}$ : Useful energy gained by solar collecting system, MJ

$Q_{t r}$ : Amount of alternative energy, kgce

$Q_{z}: \quad$ Total energy consumption, $\mathrm{MJ}$

$P: \quad$ Price of conventional energy, RMB¥/kWh

$M_{r}: \quad$ Cost for system maintenance, RMB¥ 
TABLE 13: Test results for a solar air-conditioning system during cooling conditions.

\begin{tabular}{lcccccr}
\hline Number & $\begin{array}{c}\text { Ambient temperature } \\
{ }^{\circ} \mathrm{C}\end{array}$ & $\begin{array}{c}\text { Solar irradiation } \\
\mathrm{MJ} / \mathrm{m}^{2}\end{array}$ & $\begin{array}{c}\text { Useful heat gain } \\
\mathrm{MJ}\end{array}$ & $\begin{array}{c}\text { Efficiency of solar } \\
\text { collecting system }\end{array}$ & $\begin{array}{c}\text { Solar energy } \\
\text { fraction }\end{array}$ & $\begin{array}{c}\text { COP of absorption } \\
\text { chiller }\end{array}$ \\
\hline 1 & 36.0 & 25.6 & 6551.6 & 0.56 & 1.00 & 0.81 \\
2 & 30.7 & 16.3 & 3948.0 & 0.53 & 1.00 & 0.82 \\
3 & 32.7 & 11.5 & 1944.5 & 0.37 & 0.57 & 0.70 \\
4 & 27.4 & 6.1 & 1115.1 & 0.40 & 0.09 & 0.65 \\
\hline
\end{tabular}

TABLE 14: Test results for a solar air-conditioning system during heating conditions.

\begin{tabular}{lcccccc}
\hline Number & $\begin{array}{c}\text { Ambient temperature } \\
{ }^{\circ} \mathrm{C}\end{array}$ & $\begin{array}{c}\text { Solar irradiation } \\
\mathrm{MJ} / \mathrm{m}^{2}\end{array}$ & $\begin{array}{c}\text { Useful heat gain } \\
\mathrm{MJ}\end{array}$ & $\begin{array}{c}\text { Efficiency of solar } \\
\text { collecting system }\end{array}$ & $\begin{array}{c}\text { Total energy } \\
\text { consumption }\end{array}$ & $\begin{array}{c}\text { Solar energy } \\
\text { fraction }\end{array}$ \\
\hline 1 & -4.2 & 7.34 & 1261.2 & 0.38 & 3596.1 & 0.35 \\
2 & -3.4 & 14.43 & 3027.2 & 0.46 & 3763.5 & 0.80 \\
3 & 2.2 & 11.49 & 2237.4 & 0.43 & 2935.7 & 0.76 \\
4 & 0.7 & 16.66 & 3524.1 & 0.46 & 3976.1 \\
\hline
\end{tabular}

$t_{\mathrm{as}(\mathrm{av})}$ : Average surrounding air temperature during the heat loss test, ${ }^{\circ} \mathrm{C}$

$t_{b j i}$ : Outlet temperature of solar collecting system, ${ }^{\circ} \mathrm{C}$

$t_{b l i}$ : Supply water temperature from the chiller, ${ }^{\circ} \mathrm{C}$

$t_{b r i}: \quad$ Return water temperature from the chiller, ${ }^{\circ} \mathrm{C}$

$t_{b z i}: \quad$ Cold water temperature for solar water heating system or return water temperature for solar space heating system or supply water temperature for solar air-conditioning system, ${ }^{\circ} \mathrm{C}$

$t_{d j i}$ : Outlet temperature of solar collecting system, ${ }^{\circ} \mathrm{C}$

$t_{d l i}$ : Return water temperature to the chiller, ${ }^{\circ} \mathrm{C}$

$t_{d r i}$ : Supply water temperature to the chiller, ${ }^{\circ} \mathrm{C}$

$t_{d z i}$ : Hot water temperature supplied by solar water heating system or the supply water temperature for solar water heating system or the return water temperature for solar air-conditioning system, ${ }^{\circ} \mathrm{C}$

$t_{f}$ : Final temperature in the tank after the heal loss test, ${ }^{\circ} \mathrm{C}$

$t_{i}$ : Initial temperature in the tank at the beginning of the heat loss test, ${ }^{\circ} \mathrm{C}$

$U_{\mathrm{SL}}$ : Heat loss coefficient of the storage tank, $\mathrm{W} /\left(\mathrm{m}^{3} \cdot \mathrm{K}\right)$

$V_{\mathrm{co}_{2}}$ : Emission factor of $\mathrm{CO}_{2}, \mathrm{~kg} / \mathrm{kgce}$

$V_{f c}:$ Emission factor of dust, $\mathrm{kg} / \mathrm{kgce}$

$V_{\mathrm{so}_{2}}$ : Emission factor of $\mathrm{SO}_{2}, \mathrm{~kg} / \mathrm{kgce}$.

\section{Greek Symbols}

$\rho_{w}: \quad$ Density of heat transfer media, $\mathrm{kg} / \mathrm{m}^{3}$

$\eta$ : $\quad$ Efficiency of solar collecting system, \%

$\eta_{t}$ : Operating efficiency of heat resource with conventional energy

$\Delta T_{(j, z, r, l) i}:$ Recording time interval, s
$\Delta T_{t}:$ Total recording time, $\mathrm{s}$

$\Delta \tau$ : The duration of the heat loss test, s.

\section{Abbreviations}

COP: Coefficient of performance

STS: Solar thermal systems in buildings

GB: Chinese national standard.

\section{Conflict of Interests}

The authors declare that there is no conflict of interests regarding the publication of this paper.

\section{Acknowledgments}

This work was funded by the Chinese National Scientific Program (2014BAJ01B03) and Applied Foundation of the China Academy of Building Research (20140109330730039). The contribution of the Beijing Collaborative Innovation Center of Energy-Saving and Emission-Reduction and the help from the people who contributed to GB/T 50801 are acknowledged.

\section{References}

[1] Y. Hang, M. Qu Ming, and F. Zhao, "Economical and environmental assessment of an optimized solar cooling system for a medium-sized benchmark office building in Los Angeles, California," Renewable Energy, vol. 36, no. 2, pp. 648-658, 2011.

[2] B. Lin and H. Liu, "China's building energy efficiency and urbanization," Energy and Buildings, vol. 86, pp. 356-365, 2015.

[3] European Commission (EC), Green-Paper-Towards a European Strategy for the Security of Energy Supply, COM 769, Commission of the European Communities, Brussels, Belgium, 2000.

[4] IPCC, Climate Change 2013: The Physical Science Basis, Cambridge University Press, Cambridge, UK, 2013. 
[5] K. H. Solangi, M. R. Islam, R. Saidur, N. A. Rahim, and H. Fayaz, "A review on global solar energy policy," Renewable and Sustainable Energy Reviews, vol. 15, no. 4, pp. 2149-2163, 2011.

[6] T. Kousksou, A. Allouhi, M. Belattar et al., "Renewable energy potential and national policy directions for sustainable development in Morocco," Renewable and Sustainable Energy Reviews, vol. 47, pp. 46-57, 2015.

[7] A. Allouhi, A. Jamil, T. Kousksou, T. El Rhafiki, Y. Mourad, and Y. Zeraouli, "Solar domestic heating water systems in Morocco: an energy analysis," Energy Conversion and Management, vol. 92, pp. 105-113, 2015.

[8] H. Xie, C. Zhang, B. Hao, S. Liu, and K. Zou, "Review of solar obligations in China," Renewable and Sustainable Energy Reviews, vol. 16, no. 1, pp. 113-122, 2012.

[9] S. Mekhilef, A. Safari, W. E. S. Mustaffa, R. Saidur, R. Omar, and M. A. A. Younis, "Solar energy in Malaysia: current state and prospects," Renewable and Sustainable Energy Reviews, vol. 16, no. 1, pp. 386-396, 2012.

[10] S. Mekhilef, R. Saidur, and A. Safari, "A review on solar energy use in industries," Renewable and Sustainable Energy Reviews, vol. 15, no. 4, pp. 1777-1790, 2011.

[11] D. Ürge-Vorsatz, L. F. Cabeza, S. Serrano, C. Barreneche, and K. Petrichenko, "Heating and cooling energy trends and drivers in buildings," Renewable and Sustainable Energy Reviews, vol. 41, pp. 85-98, 2014.

[12] U. Stritih, E. Osterman, H. Evliya, V. Butala, and H. Paksoy, "Exploiting solar energy potential through thermal energy storage in Slovenia and Turkey," Renewable and Sustainable Energy Reviews, vol. 25, pp. 442-461, 2013.

[13] M. S. Mohsen and B. A. Akash, "Evaluation of domestic solar water heating system in Jordan using analytic hierarchy process," Energy Conversion and Management, vol. 38, no. 18, pp. 1815-1822, 1997.

[14] R. Zheng, T. He, X. Zhang, Z. Huang, and Y. Deng, "Developing situation and energy saving effects for solar heating and cooling in China," Energy Procedia, vol. 30, pp. 723-729, 2012.

[15] E. Halawa, K. C. Chang, and M. Yoshinaga, "Thermal performance evaluation of solar water heating systems in Australia, Taiwan and Japan-A comparative review," Renewable Energy, vol. 83, pp. 1279-1286, 2015.

[16] L. M. Ayompe and A. Duffy, "Thermal performance analysis of a solar water heating system with heat pipe evacuated tube collector using data from a field trial," Solar Energy, vol. 90, pp. 17-28, 2013.

[17] M. Qu, H. Yin, and D. H. Archer, "A solar thermal cooling and heating system for a building: experimental and model based performance analysis and design," Solar Energy, vol. 84, no. 2, pp. 166-182, 2010.

[18] A. M. Papadopoulos, S. Oxizidis, and N. Kyriakis, "Perspectives of solar cooling in view of the developments in the air-conditioning sector," Renewable and Sustainable Energy Reviews, vol. 7, no. 5, pp. 419-438, 2003.

[19] M. Mazloumi, M. Naghashzadegan, and K. Javaherdeh, "Simulation of solar lithium bromide-water absorption cooling system with parabolic trough collector," Energy Conversion and Management, vol. 49, no. 10, pp. 2820-2832, 2008.

[20] J. D. Marcos, M. Izquierdo, and D. Parra, "Solar space heating and cooling for Spanish housing: potential energy savings and emissions reduction," Solar Energy, vol. 85, no. 11, pp. 26222641, 2011.
[21] G. A. Florides, S. A. Kalogirou, S. A. Tassou, and L. C. Wrobel, "Modelling and simulation of an absorption solar cooling system for Cyprus," Solar Energy, vol. 72, no. 1, pp. 43-51, 2002.

[22] X. Q. Zhai and R. Z. Wang, "A review for absorbtion and adsorbtion solar cooling systems in China," Renewable and Sustainable Energy Reviews, vol. 13, no. 6-7, pp. 1523-1531, 2009.

[23] A. P. Ferreira Leite, F. A. Belo, M. M. Martins, and D. B. Riffel, "Central air conditioning based on adsorption and solar energy," Applied Thermal Engineering, vol. 31, no. 1, pp. 50-58, 2011.

[24] K. F. Fong, T. T. Chow, C. K. Lee, Z. Lin, and L. S. Chan, "Comparative study of different solar cooling systems for buildings in subtropical city," Solar Energy, vol. 84, no. 2, pp. 227-244, 2010

[25] L. Juanicó, "A new design of roof-integrated water solar collector for domestic heating and cooling," Solar Energy, vol. 82, no. 6, pp. 481-492, 2008.

[26] A. Hobbi and K. Siddiqui, "Optimal design of a forced circulation solar water heating system for a residential unit in cold climate using TRNSYS," Solar Energy, vol. 83, no. 5, pp. 700-714, 2009.

[27] C.-D. Yue and G.-R. Huang, "An evaluation of domestic solar energy potential in Taiwan incorporating land use analysis," Energy Policy, vol. 39, no. 12, pp. 7988-8002, 2011.

[28] S. A. Kalogirou, "Environmental benefits of domestic solar energy systems," Energy Conversion and Management, vol. 45, no. 18-19, pp. 3075-3092, 2004.

[29] S. A. Kalogirou, "Solar thermal collectors and applications," Progress in Energy and Combustion Science, vol. 30, no. 3, pp. 231-295, 2004.

[30] G. Ozyogurtcu, M. Mobedi, and B. Ozerdem, "Technoeconomic evaluation of a ventilation system assisted with exhaust air heat recovery, electrical heater and solar energy," Energy and Buildings, vol. 72, pp. 17-23, 2014.

[31] T. Tsoutsos, N. Frantzeskaki, and V. Gekas, "Environmental impacts from the solar energy technologies," Energy Policy, vol. 33, no. 3, pp. 289-296, 2005.

[32] A. Al-Salaymeh, I. Al-Rawabdeh, and S. Emran, "Economical investigation of an integrated boiler-solar energy saving system in Jordan," Energy Conversion and Management, vol. 51, no. 8, pp. 1621-1628, 2010.

[33] H. Zhai, Y. J. Dai, J. Y. Wu, and R. Z. Wang, "Energy and exergy analyses on a novel hybrid solar heating, cooling and power generation system for remote areas," Applied Energy, vol. 86, no. 9, pp. 1395-1404, 2009.

[34] O. Ozgener and A. Hepbasli, "A parametrical study on the energetic and exergetic assessment of a solar-assisted vertical ground-source heat pump system used for heating a greenhouse," Building and Environment, vol. 42, no. 1, pp. 11-24, 2007.

[35] O. Ozgener and A. Hepbasli, "Experimental performance analysis of a solar assisted ground-source heat pump greenhouse heating system," Energy and Buildings, vol. 37, no. 1, pp. 101-110, 2005.

[36] I. M. Michaelides and P. C. Eleftheriou, "An experimental investigation of the performance boundaries of a solar water heating system," Experimental Thermal and Fluid Science, vol. 35, no. 6, pp. 1002-1009, 2011.

[37] R. Sekret and M. Turski, "Research on an adsorption cooling system supplied by solar energy," Energy and Buildings, vol. 51, pp. 15-20, 2012. 
[38] D. Xu, Q. Liu, J. Lei, and H. Jin, "Performance of a combined cooling heating and power system with mid-and-low temperature solar thermal energy and methanol decomposition integration," Energy Conversion and Management, vol. 102, pp. 17-25, 2015.

[39] M. Esen and T. Yuksel, "Experimental evaluation of using various renewable energy sources for heating a greenhouse," Energy and Buildings, vol. 65, pp. 340-351, 2013.

[40] M. M. Kablan, "Techno-economic analysis of the Jordanian solar water heating system," Energy, vol. 29, no. 7, pp. 1069-1079, 2004.

[41] J. Yoo, "Evaluation of solar hot water heating system applications to high-rise multi-family housing complex based on three years of system operation," Energy and Buildings, vol. 101, pp. 54-63, 2015.

[42] T.-T. Chow, Z. Dong, L.-S. Chan, K.-F. Fong, and Y. Bai, "Performance evaluation of evacuated tube solar domestic hot water systems in Hong Kong," Energy and Buildings, vol. 43, no. 12, pp. 3467-3474, 2011.

[43] U. Desideri, S. Proietti, and P. Sdringola, "Solar-powered cooling systems: technical and economic analysis on industrial refrigeration and air-conditioning applications," Applied Energy, vol. 86, no. 9, pp. 1376-1386, 2009.

[44] X. Zhang, S. You, W. Xu et al., "Test result analysis of the stagnation effect on the thermal performance of solar collector," Energy Procedia, vol. 30, pp. 824-828, 2012. 

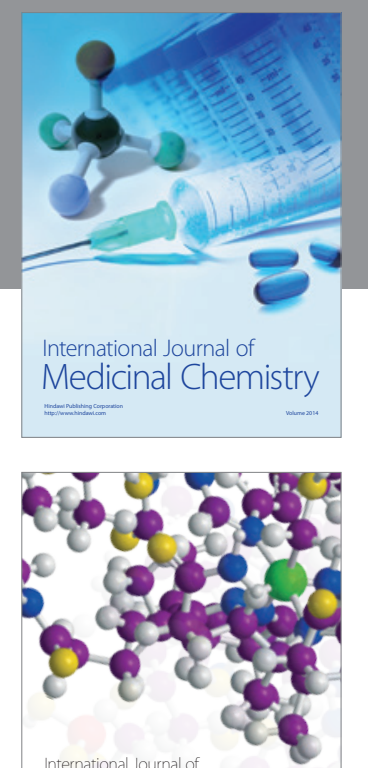

\section{Carbohydrate} Chemistry

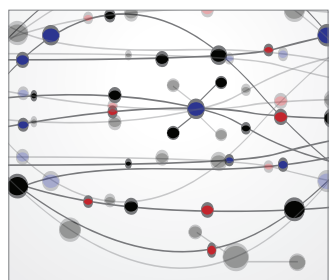

The Scientific World Journal
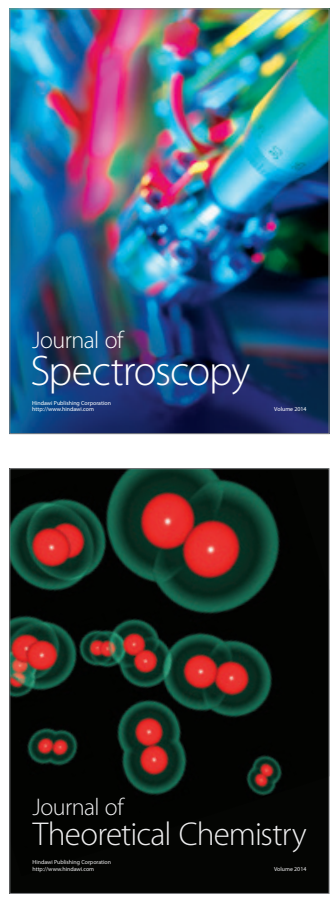
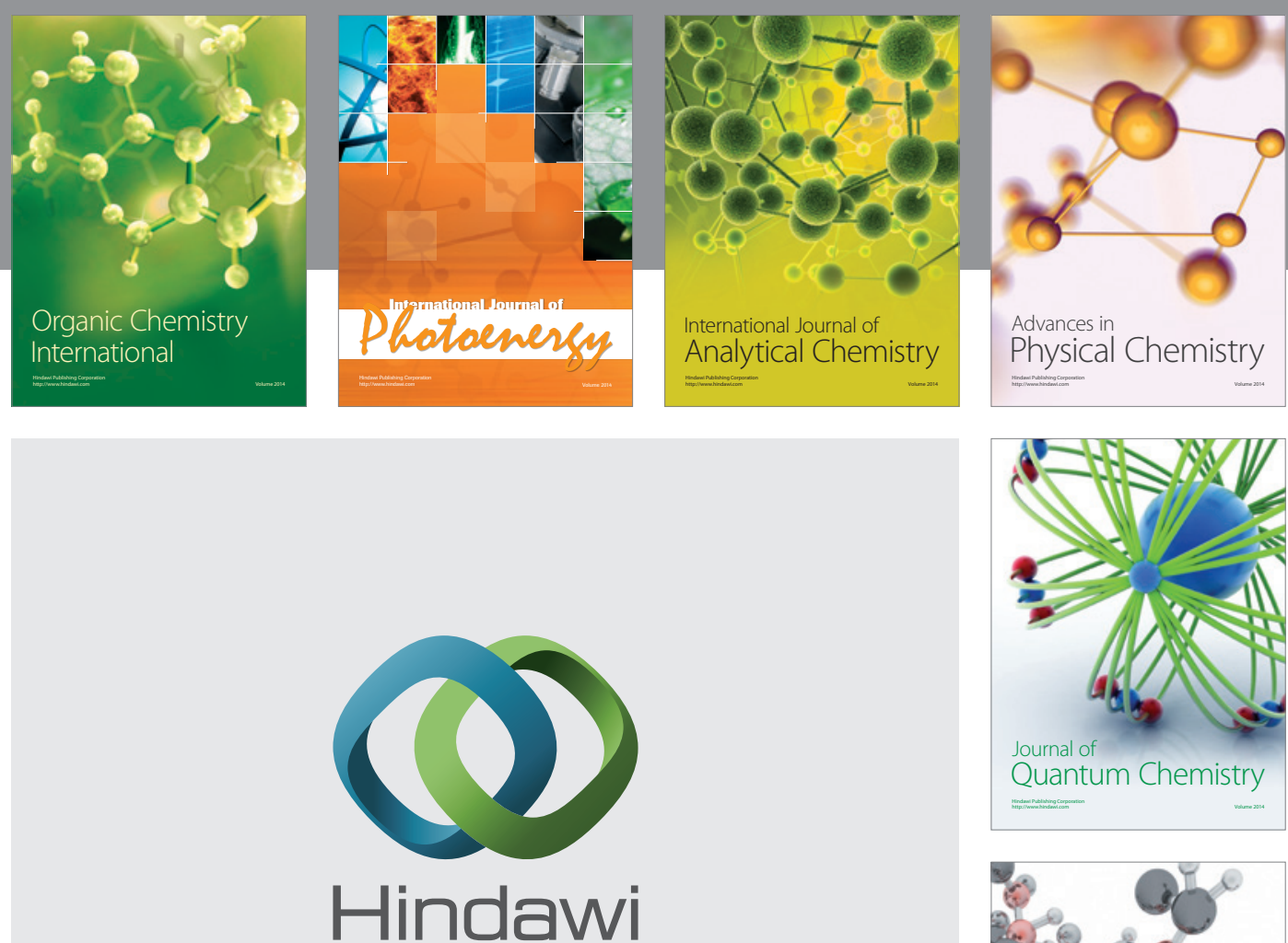

Submit your manuscripts at

http://www.hindawi.com

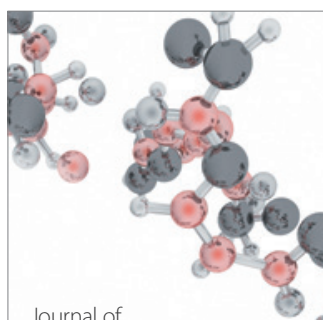

Analytical Methods

in Chemistry

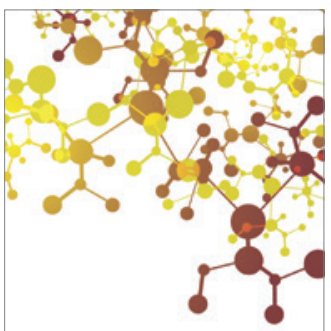

Journal of

Applied Chemistry

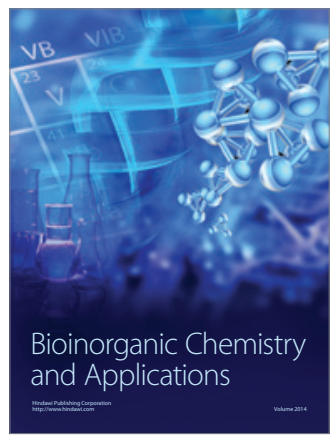

Inorganic Chemistry
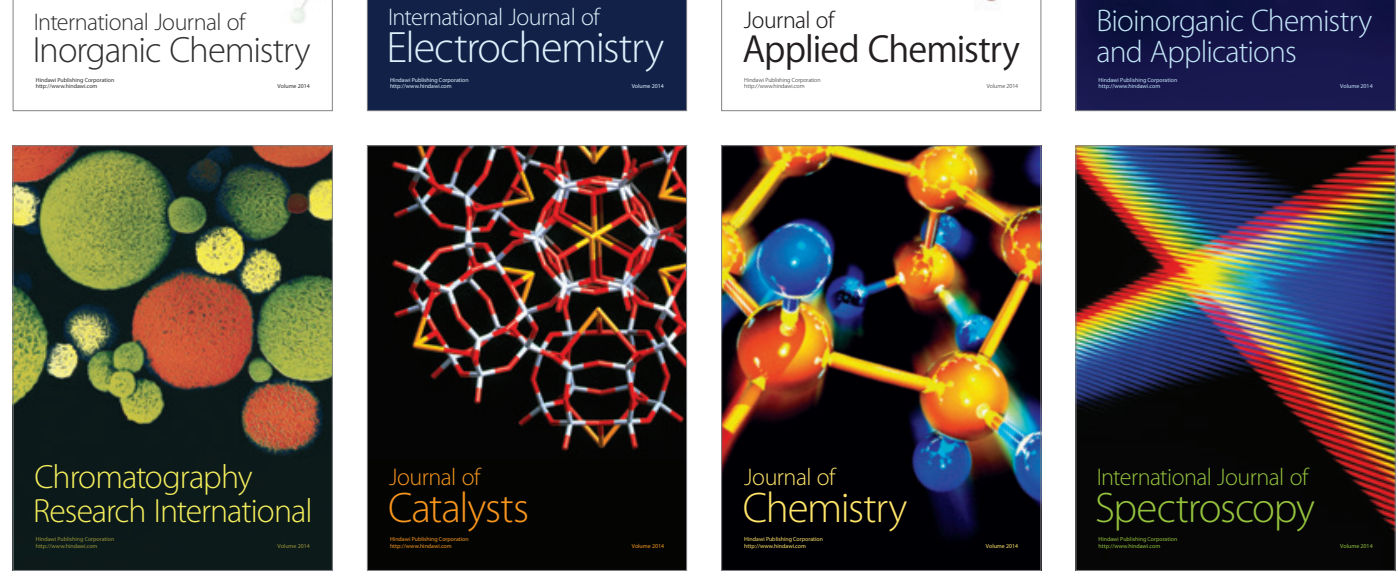